\title{
Land Cover Change Detection Using Landsat Data in Giao Thuy District, Nam Dinh Province, Vietnam
}

\author{
Nguyen Tuyet Lan a,b*, Takahiro Osawa c, I Wayan Nuarsa b, Ngo The An a \\ a Agro-ecology Department, Faculty of Environment, Vietnam National University of Agriculture (VNUA), Trau Quy \\ town, Gia Lam district, Hanoi, Vietnam \\ ${ }^{b}$ Graduate School of Environmental Sciences, Udayana University, PB Sudirman Street, Post Graduate Building, \\ Denpasar, Bali 80232, Indonesia \\ c Center for Remote Sensing and Ocean Science (CReSOS), Udayana University, PB Sudirman Street, Post Graduate \\ Building, Denpasar, Bali 80232, Indonesia \\ * Correspondence: lanquat@yahoo.com
}

Received: 8 September 2016; Accepted: 12 February 2017; Available online: 19 February 2017

\begin{abstract}
Giao Thuy located a coastal area, which has fully the characteristed of microclimate Red River delta. This study was conducted to detect the land cover changes from 2000 to 2015 and the causes. The changes are evaluated using Landsat data by method of land use classification combined with interviews. The results showed that most portion of the land cover class was crops land and land cover change was crops land decreases, forest land rises, aquaculture ponds increase, surface water reduces and unuse flat land area increases. The causes were policy issuses, market, economic, salinity intrusion, climate change and deposits alluvial.
\end{abstract}

Keywords: land cover change; landsat data; the cause of driving force

\section{Introduction}

Giao Thuy district located on the southern of the Red River delta is 26,500 ha area. Giao Thuy has fully the characteristics of microclimate Red River delta, is a tropical area, monsoon, hot, humid and rainy, with four seasons (Beland et al., 2006). Annually, Giao Thuy often affected by typhoons or tropical depressions, averaging from $4-6$ episodes/year. The extreme weather phenomena: temperature increase; rainfall change; increased frequency and severity of cold weather damage, etc combined with sea level rise, salinity intrusion is difficult for agricultural production (An and Bang, 2014).

According to the guidelines of the State, Giao Thuy also directed the communes implemented the new rural construction, combined with land consolidation embellishment field, transforming from low productivity agricultural production to aquaculture ponds, move economic restructuring to enhance economic efficiency, increase income for laborers. (Giao Thuy district People's Committee, 2013a; 2013b).

This paper conducted to analyzing land cover change and the causes of land cover change from 2000 - 2015 in Giao Thuy district. Aim of this study provided more information about land cover changes and how much area did land cover change in each class.

\section{Materials and Methods}

\subsection{Research Location}

Giao Thuy district is located $20^{\circ} 10$ 'to $20^{\circ} 21^{\prime} \mathrm{N}$ and $106^{\circ} 21^{\prime}$ to $106^{\circ} 35^{\prime} \mathrm{E}$. Giao Thuy District is located in the coastal zone of the Red River Delta Provinces of lowland northern 
Vietnam. It is bordered by the Ba Lat estuary (the largest estuary of the Red River Basin) to the north, the Eastern Sea and Hai Hau District to the south, and Xuan Truong District (part of the former Xuan Thuy District) to the west (Adger et al., 2002).

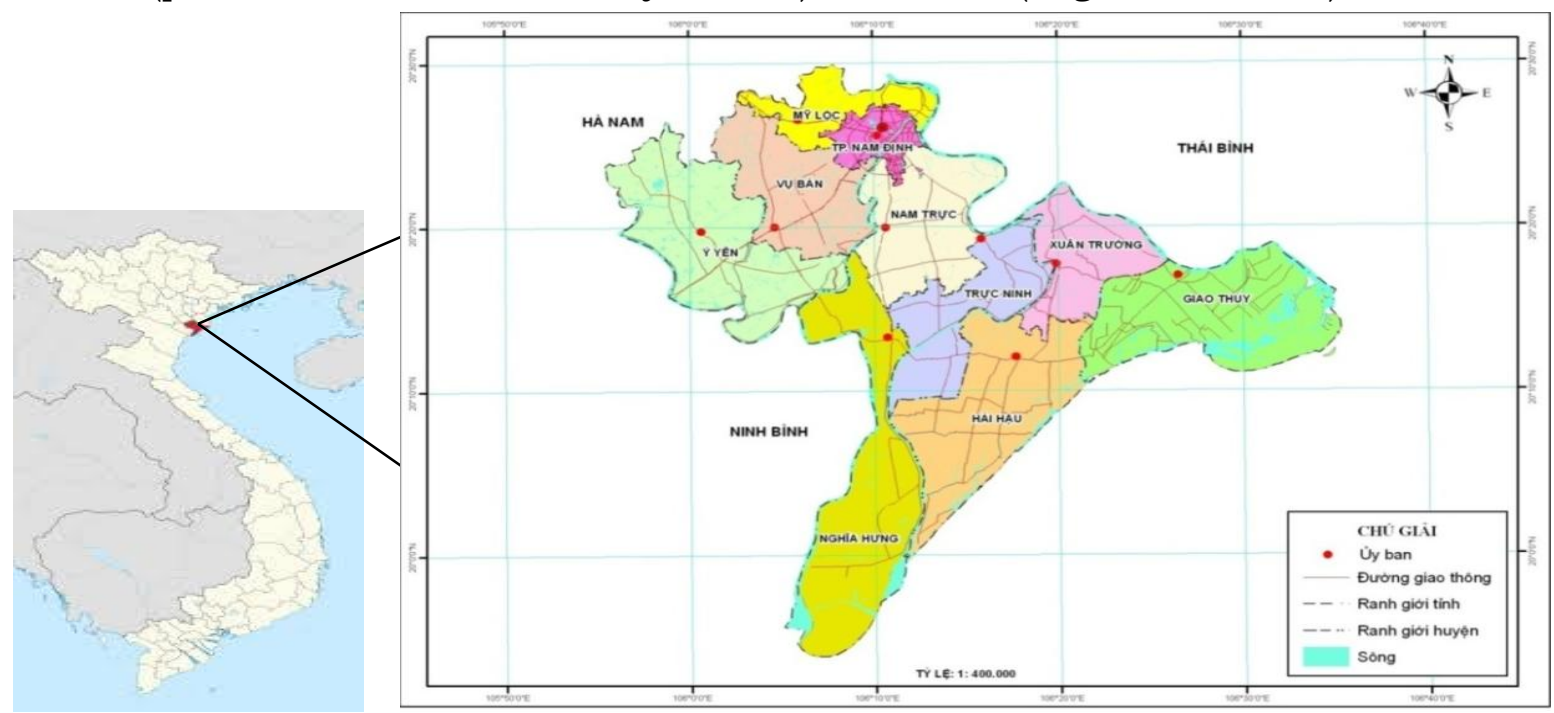

Figure 1. Map of research location

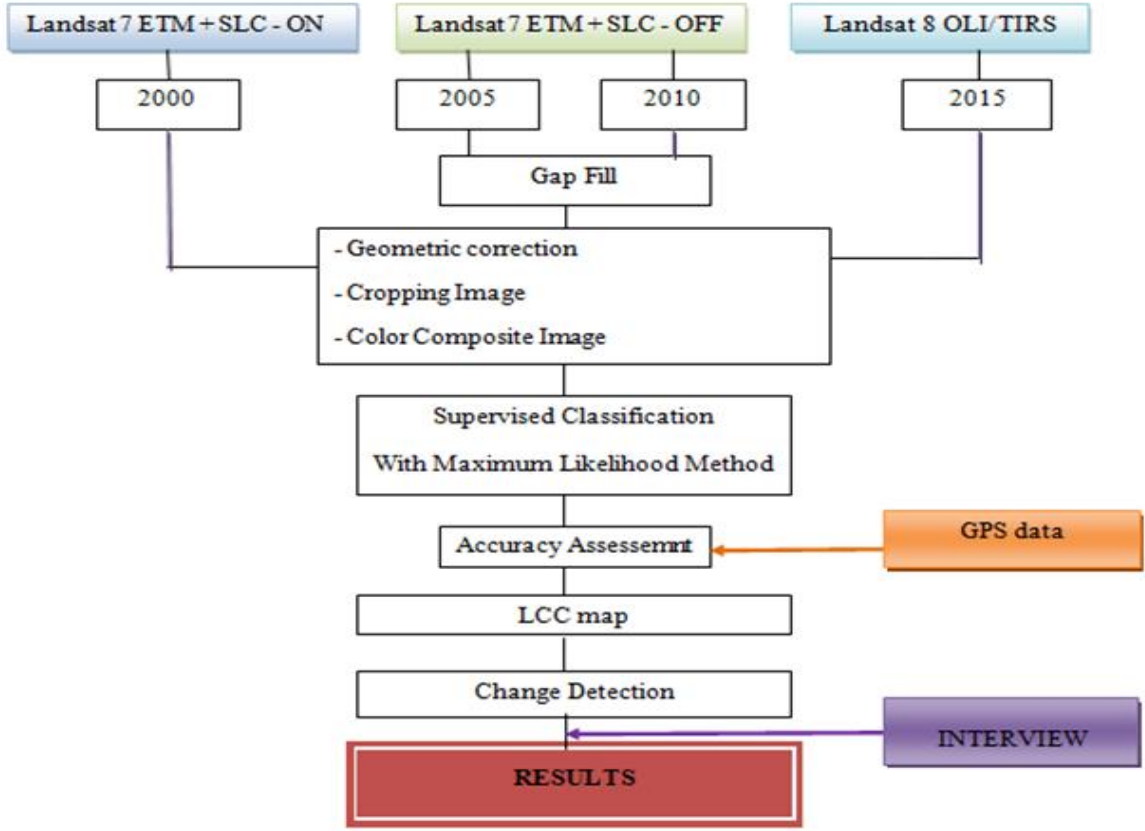

Figure 2. Framework of research.

\subsection{Research Scope}

This study is about the process of land cover changes, includes vegetation areas (crops land, forests land), surface water areas (aquaculture ponds, surface water - river, channel and sea water) and unused flat land areas (barren land, unused land and mudflats) during $2000-2015$.

\subsection{Land Cover Change Detection}

Landsat data in 2000, 2005, 2010 and 2015 were classified the land use by supervise classification with Maximum Likelihood method to particular seven catelogies, namely: built - up land, crops land, forest land, river - channel, sea surface water, aquaculture ponds and un used flat land. 


\subsection{The Causes of Driving Force of Land Cover Change}

It was identified by interview households by structure questionnaire and officers who work in Giao Thuy District People's Committee by focus group discussion. Figure 2 illustrated the framework of current research.

\section{Results and Discussion}

\subsection{Land Cover Change Detection}

The classification results in research location Giao Thuy district in 2000, 2005, 2010 and 2015 with seven categories including crops land, built-up land, river channel, sea surface water, aquaculture ponds, forest land and un used flat land are shown in Figure 3.
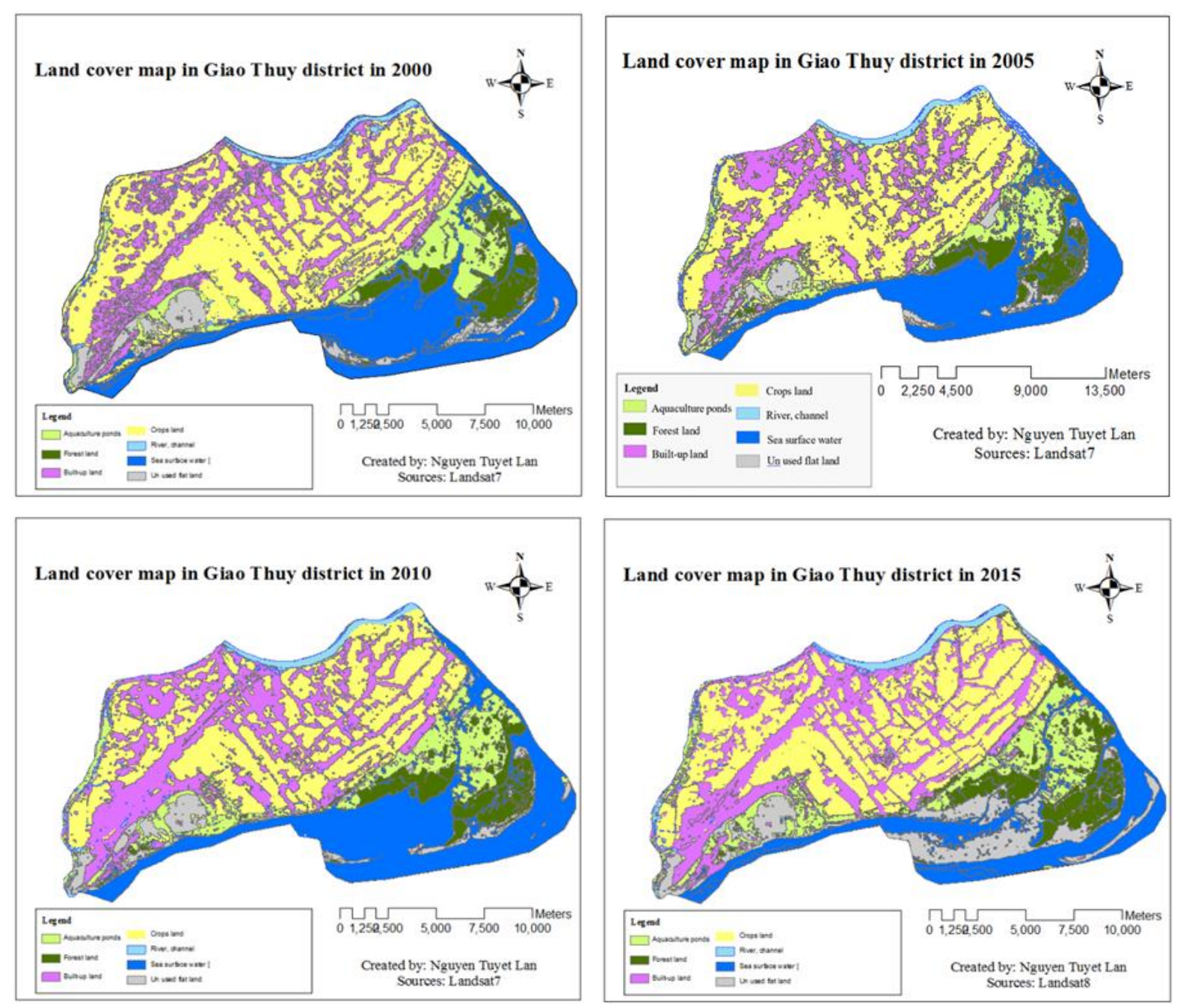

Figure 3. Land cover classification map in Giao Thuy district in 2000 (top left), 2005 (top right), 2010 (bottom left), and 2015 (bottom right).

Table 1 showed the total area of Giao Thuy is 26,500 ha. The percentages of land cover for 2000 are crops land $(36.2 \%)$, forest land $(5.7 \%)$, aquaculture ponds $(7.9 \%)$, surface water $(25.1 \%)$, and un used flat land $(6.1 \%)$. There are crops land $(30.6 \%)$, forest land $(5.9 \%)$, aquaculture ponds $(8.9 \%)$, the remaining $25.3 \%$ is surface water and un used flat land $(5.2 \%)$ in percent coverage of 2005. Crops land, forest land, aquaculture ponds, surface water, and un use flat land amounted to about $29.4 \%, 6.4 \%, 9.8 \%, 24.5 \%$ and $5.8 \%$ in 2010 . Finally, for 2015 crops land and forest land accounting for $29.4 \%$ and $7.2 \%$, while aquaculture ponds, surface water and un use flat land amounted to about 
$10.2 \%, 17.9 \%$ and $11.0 \%$. Most portion of the land cover class was crops land during this period.

Table 1. Land cover classes in Giao Thuy district from 2000 - 2015

\begin{tabular}{|c|c|c|c|c|c|c|c|c|c|}
\hline & \multirow{2}{*}{ Class name } & \multicolumn{2}{|c|}{2000} & \multicolumn{2}{|c|}{2005} & \multicolumn{2}{|c|}{2010} & \multicolumn{2}{|c|}{2015} \\
\hline & & Area (ha) & $\%$ & Area (ha) & $\%$ & Area (ha) & $\%$ & Area (ha) & $\%$ \\
\hline 1 & Crops land & $9,591.3$ & 36,2 & $8,106.9$ & 30,6 & $7,803.1$ & 29,4 & $7,796.7$ & 29,4 \\
\hline 2 & Built-up land & $5,047.2$ & 19,0 & $6,363.4$ & 24,0 & $6,364.2$ & 24,0 & $6,436.3$ & 24,3 \\
\hline 3 & Surface water & $6,650.1$ & 25,1 & $6,712.0$ & 25,3 & $6,493.5$ & 24,5 & $4,750.0$ & 17,9 \\
\hline 4 & Aquaculture ponds & $2,083.4$ & 7,9 & $2,366,7$ & 8,9 & $2,599.5$ & 9,8 & $2,695.7$ & 10,2 \\
\hline 5 & Forest land & $1,502.5$ & 5,7 & $1,564.2$ & 5,9 & $1,695.7$ & 6,4 & $1,897.4$ & 7,2 \\
\hline 6 & Un used flat land & $1,625.1$ & 6,1 & $1,388.4$ & 5,2 & $1,543.6$ & 5,8 & $2,923.5$ & 11,0 \\
\hline \multicolumn{2}{|c|}{ Total Area } & $26,499.6$ & 100 & $26,499.6$ & 100 & $26,499.6$ & 100 & $26,499.6$ & 100 \\
\hline
\end{tabular}

Table 2. Change detection in Giao Thuy district periods $2000-2015$

\begin{tabular}{|c|c|c|c|c|c|c|c|c|}
\hline \multirow{2}{*}{\multicolumn{2}{|c|}{ Class name }} & \multicolumn{6}{|c|}{2015 (ha) } & \multirow{2}{*}{$\begin{array}{c}\text { Area } 2000 \\
\text { (ha) }\end{array}$} \\
\hline & & $\begin{array}{l}\text { Crops } \\
\text { land }\end{array}$ & $\begin{array}{c}\text { Built-up } \\
\text { land }\end{array}$ & $\begin{array}{c}\text { Surface } \\
\text { water }\end{array}$ & $\begin{array}{l}\text { Aquaculture } \\
\text { ponds }\end{array}$ & $\begin{array}{c}\text { Forest } \\
\text { land }\end{array}$ & $\begin{array}{l}\text { Un used } \\
\text { flat land }\end{array}$ & \\
\hline \multirow{6}{*}{$\begin{array}{c}2000 \\
\text { (ha) }\end{array}$} & Crops land & 7,684 & 1,220 & 155 & 430 & 103 & - & 9,592 \\
\hline & Built-up land & - & 5,047 & - & - & - & - & 5,047 \\
\hline & Surface water & - & 139 & 4,284 & 335 & 73 & 1,820 & 6,650 \\
\hline & $\begin{array}{l}\text { Aquaculture } \\
\text { ponds }\end{array}$ & - & - & 85 & 1,876 & 123 & - & 2,084 \\
\hline & Forest land & - & - & - & - & 1,502 & - & 1,502 \\
\hline & $\begin{array}{l}\text { Un used flat } \\
\text { land }\end{array}$ & 113 & 30 & 227 & 55 & 97 & 1,103 & 1.625 \\
\hline \multicolumn{2}{|c|}{ Area 2015 (ha) } & 7,797 & 6,436 & 4,751 & 2,696 & 1,898 & 2,923 & 26,500 \\
\hline
\end{tabular}

During 2000 - 2015 in Giao Thuy district, land cover change detection (Table 2) indicated that decrease in crops land was due to conversion into built-up land and aquaculture ponds; which amounted built-up land $(1,220.4$ ha $-(12.7 \%))$ and aquaculture ponds $(429.6 \mathrm{ha}-(4.5 \%))$. Built-up land category has increased 1.27 times (from 5,047.3 ha in 2000 to 6,436.3 ha in 2015) due to crops land was converted. Strong relationship between surface water and un used flat land and $27.3 \%(1,820.2 \mathrm{ha})$ of surface water is converted to un used flat land. Aquaculture ponds category has increased at the expense of crops land and surface water which accounts to $16 \%$ and $12.4 \%$ respectively. 5.9\% aquaculture ponds area (122.6 ha) and $1.1 \%$ crop land area (102.9 ha) in 2000 were converted into forest land area in 2015 to make increase forest land area.

\subsection{The Causes of Land Cover Change}

Figure4 showed land cover change in Giao Thuy period 2000 - 2015 are presented as follows: vegetation areas (crops land decreased, forest land rised), surface water areas (aquaculture ponds increased, surface water reduced) and unuse flat land areas increased. Land cover change in study location during 2000 to 2015 is due to several reasons. Crops land has tended to decrease between 2000 and 2015. There is strong relationship between built-up land and aquaculture ponds are converted to crops land during the fifteen years. Population growth was the major reasons for the changes which took place on crops land. There is linked to growth in population and its density to make increasing the demand for shelter, housing. Therefore, it made crops land and built-up land change conflicting. In 2002, Giao Thuy district has policy about encouraging land use conversion from rice land into aquaculture ponds to increase income and improve people's lives. 


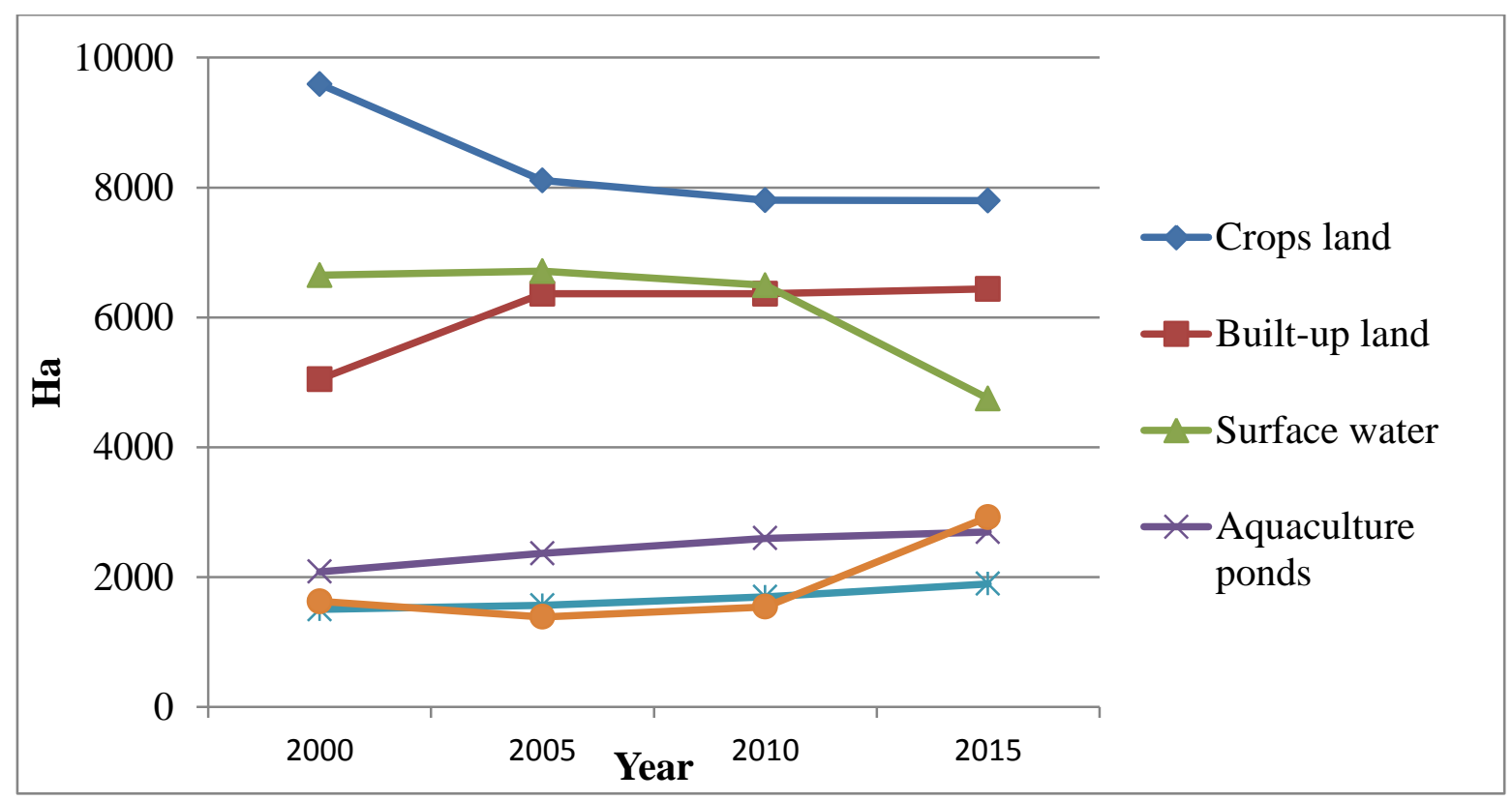

Figure 4. Land cover change in Giao Thuy district from $2000-2015$.

Table 3. The cause of land cover change during $2000-2015$ in Giao Thuy district

\begin{tabular}{|c|c|c|c|}
\hline No & The cause of land cover change & Yes (\%) & No $(\%)$ \\
\hline 1 & Policy issues & 85 & 15 \\
\hline 2 & Market and Economic & 80 & 20 \\
\hline 3 & Salinity intrusion & 45 & 55 \\
\hline 4 & Climate change & 50 & 50 \\
\hline
\end{tabular}

This was sense in legal, as well as orientation to the people can get the consent of the government when convert the land use purpose. Paddy low productivity, low income is affected by the salinity intrusion and storm and flood as being broken rice, failure crop and low productivity. Area of land converted from crops land to aquaculture ponds is mainly coastal areas along the dyke as it has influenced mainly by the above reasons from 2005 (Figure3). Moreover, it was also influenced by the needs of the market and the economy. The market has a high demand for seafood and clam, fish brings higher economic efficiency, economic value than rice. Famers identified the causes what converted from crops land into aquaculture ponds are shown in Table 3.

Table 3 shows $85 \%$ of famers interviewed answered policy issues, $80 \%$ market and economic, $45 \%$ salinity intrusion and $50 \%$ climate change (mainly $90 \%$ of famers near the dyke noticed the affect of salinity intrusion and climate change) were influenced to decide conversion of land use purposes from crops land to aquaculture ponds. In these factors affecting the conversion of land use purposes, famers said that economic and market the most important factors affecting to decide the conversion of land use purpose by weighted scoring method.

Forest land has tended to rising during 2000 to 2015. They include protection forests and mangroves in Giao Thuy district. The majority of the forest land located at southeast is mangroves. Figure 2 showed forest land area increased mainly crops land converted to protection forests and from aquaculture ponds to mangroves. This is due to the local government had noticed the role of protection forests against wind, sand and storms and mangroves to the effects of climate change. Giao Thuy also has Xuan Thuy National Park located in the core zone Biosphere Reserve south of the Red River delta was organized by 
UNESCO. Therefore, they usually maintain, protect existing forest area and plant more in some new areas.

Finally, there was strong relationship between changing trends of surface water and un used flat land and $27.3 \%$ of surface water was converted to un use flat land during the fifteen years from 2000. Un used flat land in here in 2015 increased and surface water decreased opposite significantly due to many new mudflats appeared by the deposits alluvial annual (Figure2).

\section{Conclusions}

Driving force of land cover change in Giao Thuy district period 2000 - 2015 was presented as follows: vegetation areas (crops land decreased (39.2-29.4\%), forest land rised (5.6-7.2\%)), surface water areas (aquaculture ponds increased (8.9-10.2\%), surface water reduced (25.1-17.9\%)) and unuse flat land areas increased (5.2-11\%). Most portion of the land cover class was crops land during this period. Due to policy issuses, market, economic, salinity intrusion, climate change and deposits alluvial. Economic and market what are the most important factors affected to deciding the conversion of land use purpose of famers.

\section{References}

Adger, W. N., Kelly, P. M., Winkels, A., Huy, L. Q., \& Locke, C. (2002). Migration, remittances, livelihood trajectories, and social resilience. AMBIO: A Journal of the Human Environment, 31(4), 358-366.

An, N. T., \& Bang, T. N. (2014). Climate change adaptation in agricultural systems of Giao Thuy district: An analysis from GIS-based modeling and participatory approach. In proceedings of 8th asian crop science association conference. Hanoi, Vietnam.

Beland, M., Goita, K., Bonn, F., \& Pham, T. T. H. (2006). Assessment of land - cover changes related to shrimp aquaculture using remote sensing data: a case study in the Giao Thuy District, Vietnam. International Journal of Remote Sensing, 27(8), 1491-1510.

Giao Thuy district People's Committee. (2013a). Notes to consolidated - Land use planning to 2020, Land use plan states 5 years (2011-2015) Giao Thuy district, Nam Dinh provine. Giao Thuy district People's Committee.

Giao Thuy district People's Committee. (2013b). The action plan to cope with climate change Giao Thuy district's 2011-2015 Vision 2020. Giao Thuy district People's Committee.

(C) 2017 by the authors; licensee Udayana University, Indonesia. This article is an open access article distributed under the terms and conditions of the Creative Commons Attribution (CC-BY) license (http://creativecommons.org/licenses/by/4.0/). 